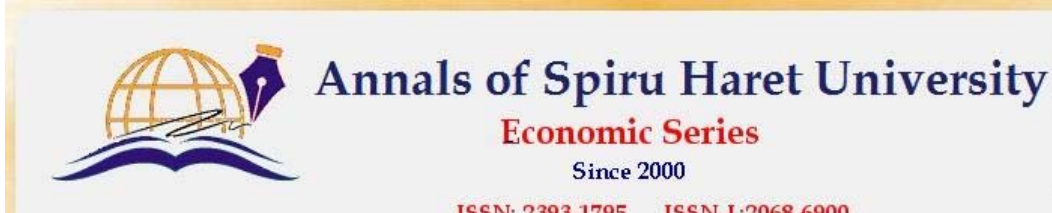

ISSN: 2393-1795 ISSN-L-2068-6900

Issue 1/2018

\title{
FOREWORD
}

Shanta Devarajan, who is the Senior Director at the Development Economics World Bank, said recently, in a forecasting about global economic growth at the beginning of 2018, that currently there is a set of optimistic projections for economic growth around the world. Ten years after the global financial crisis, every economic region - from the U.S. to Europe to Asia, Africa, and Latin America - is seeing an uptick in growth. One reason for the optimism is that economic growth was surprisingly better than anticipated in 2017. Almost every growth forecast at the beginning of the year was revised upward by the end of the year. Global growth, projected by the World Bank to be $2.7 \%$ in January 2017, was estimated at 3 percent in December, with expectation to be at 3.1 percent in 2018. Furthermore, stock markets are booming. And the factors that caused growth to be subdued in the past a slowdown in investment and trade and low commodity prices - are rebounding. Consequently, developing country growth is forecasted at a robust 4.5 percent in 2018, accelerating to 4.7 percent in the subsequent two years. This growth is not just driven by China, although the country's economy is projected to grow at a robust 6.4 percent in 2018. Low-income countries' growth will rise to 5.4 percent in 2018, accelerating to 5.6 percent in 2019-2020, as metal and mineral prices strengthen.

At the same time, the World Bank's Global Economic Prospects estimates that potential growth - the pace at which the economy could grow if all factors were fully employed - is likely to slowdown in the future. Why? It is important to understand that potential growth is never directly observed: It is outside the frame. Therefore, the World Bank uses several observations to make this prediction:

First, the slowdown in investment over the past five years means that these economies' capital stock has not been growing as fast. Second, in every region except Africa, the percent of people participating in the labour force is shrinking. Third, total factor productivity (TFP) - a measure of the output generated over and above that attributed to labour and capital - has been slowing, initially in developed countries, and more recently in developing countries. If these estimates are correct, the slowing of potential growth can constrain how high and how long the current upsurge in growth can go.

Potential growth is a measure of the economy's capacity. Since the global financial crisis, the global economy has been operating below capacity. The "global 


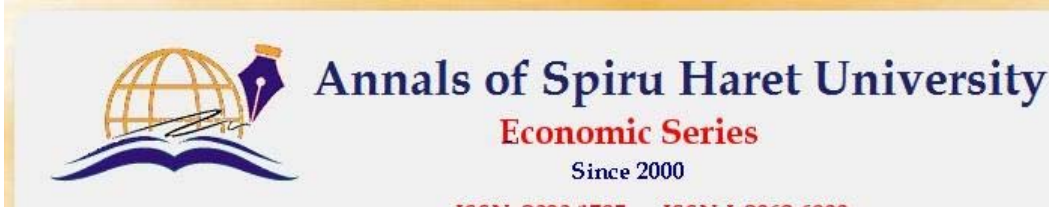

ISSN: 2393-1795 ISSN-L:2068-6900

\section{Issue 1/2018}

output gap" has been particularly sharp for advanced economies, which were at the centre of the global financial crisis. Developing countries have closed the output gap more recently, although commodity exporters are still facing a significant shortfall. The combination of limited growth in the economy's capacity and acceleration of actual growth means that the output gap is about to close very quickly.

Coming very close to these trends, and helping to better understand the economic factors that influence the world economy, there is also the topic of our journal articles. Their topics are quite varied and start from forms of partnerships between universities and companies and end with problems related to the evolution of online tourism.

In the first article of this issue, the University sector in the national innovation system (NIS) is considered as one of the key players which links new knowledge with the industry for the purpose of diffusing new knowledge for economic and social benefits through commercialization of products, services, processes and other artefacts. This paper inquires the role of Sri Lankan universities in the innovation process by paying special attention on the strength of university-industry linkages. Responses from the industrial sector are obtained through surveys and interviews with respondents. The study revealed a positive trend in the higher education sector towards performing effective role in the future towards innovation. However, it was evident that these relationships still remained very weak. The industrial sector remains inward oriented with little intention to innovation, while universities still prioritize their traditional teaching role in higher education.

The study called Budgetary Participation and Managerial Performance in Public Sector Organisations: A Study from Nigeria investigated the impact of budgetary participation on managerial performance in public-sector organisations in Nigeria. A questionnaire was used to obtain the opinion of 174 managers (unit and departmental heads) in five public-sector organisations located in Abuja, Nigeria's Federal Capital. Results from statistical analysis (descriptive, factor analysis, Kruskal-Wallis tests, correlation and regression) show that there is high level of budgetary participation by managers in public-sector organisations in Nigeria. Although budgetary participation was observed to positively and significantly impact the managerial functions such as planning, investigating, co-ordinating, supervising, evaluating, and staffing, it exerts the most on planning. The impact of budgetary participation on managerial performance appears to be moderate. Whilst it is desirable for public-sector organisations to adopt sophisticated budgeting techniques, the study advocates for employees' motivation and deeper involvement in budget 

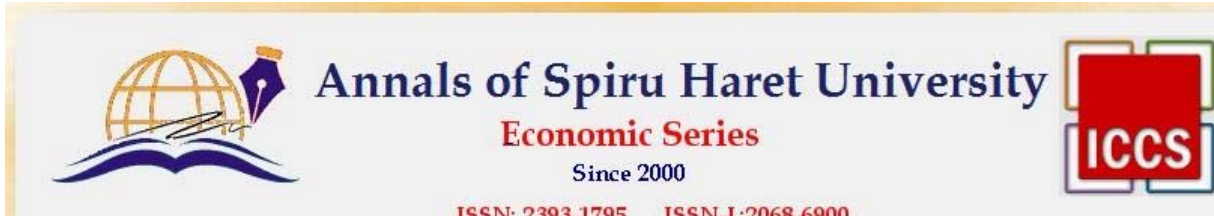

ISSN: $2393-1795 \quad$ ISSN-L-2068-6900

Issue 1/2018

matters as a way out of the traditional budgeting quagmire that public-sector organisations are characteristically bedevilled with.

In their paper, entitled Effect of international financial reporting standard on corporate performance of selected banks listed on Nigeria stock exchange, the authors, Elosiuba, J. N. and Emma Okoye, emphasize that in the light of globalisation, where foreign investment has become trendy, comparability of financial reports of Nigerian firms and those of other firms across the world has become a concern. Nigerian firms have mandated to adopt the International Financial Reporting Standard (IFRS) is their financial reporting. This study has examined the effect of the IFRS adoption on the reported performance of Nigerian banks listed on the Nigerian Stock Exchange. Eight (8) out of the fourteen (14) quoted banks were selected for the study. Four indices of performance employed in the study are profitability using the Return on Equity, Liquidity using total deposit to total loan, loan grants and then market value measured by Price earnings ratio for the period (2011 and 2012). 2011 represented GAAP era while 2012 stands for IFRS adoption. A comparability index for the banks was computed using the Excel Spreadsheet for each of the banks on each variable. Then the One Sample Test was employed for the analyses. The mean was used to answer the research question while the t-statistics tested the hypotheses. The results showed that mean values for profitability, liquidity and market value are greater in the GAAP era (2011) than in the IFRS period (2012), while loan grant has higher for IFRS period (2012). The t-tested indicated none of the variables had significant effect. Thus, the study concluded that IFRS adopted does not have significant effect on bank performance reported in 2011 and 2012. This study recommends the use of IFRS for all firms as well as incorporation of IFRS guideline in professional training.

The study about the Effect of Foreign Exchange Rate Fluctuations on Nigerian Economy investigated the effect of exchange rate fluctuations on Nigerian economy. The fixed and floating exchange eras were compared to know the exchange rate system in which the economy was fairly better. The time period covered was 1970 to 2012. The study employed the ordinary least square (OLS) multiple regression technique for the analysis. The coefficient of determination $\left(\mathrm{R}^{2}\right)$, F-test, t-test, beta and Durbin-Watson were used in the interpretation of the results. The results revealed that about $85 \%$ of the changes in macroeconomic indicators are explained in the fixed exchange era. In the floating exchange era, 99\% was explained, while the whole periods has 73\% explanatory power, hence the floating exchange era (1986 to date) is more effective in explaining economic trends in Nigeria. Also, exchange rate has significant positive effect on GDP during the fixed exchange rate era and 


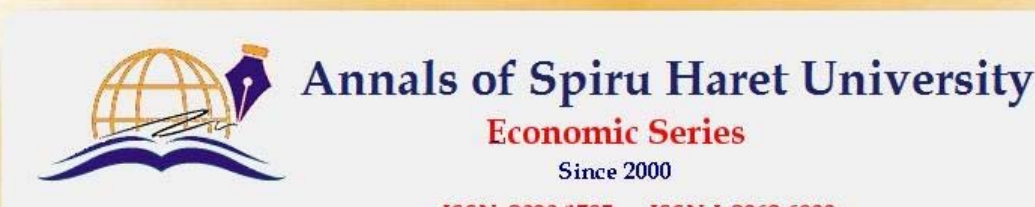

ISSN: 2393-1795 ISSN-L:2068-6900

\section{Issue 1/2018}

negative effect during the floating and all-time eras; inflation has insignificant negative effect on GDP during the fixed exchange era; significant effect in floating era and significant negative effect in the all-time period; money supply has insignificant negative effect GDP in fixed exchange era; and significant positive effect during the floating and all-time period; and oil revenue has significant positive effect on the GDP in all the exchange rate regimes (floating, fixed and all-time) in Nigeria. The study thus conclude that exchange rate movement is a good indicator for monitoring Nigerian economic growth.

The study entitled Effect of monetary policy on economic growth in Nigeria: an empirical investigation investigated the effect of monetary policy on economic growth in Nigeria. The natural log of the GDP was used as the dependent variables against the explanatory monetary policy variables: monetary policy rate, money supply, exchange rate, lending rate and investment. The time series data is the market controlled period covering 1986 to 2016. The study adopted an Ordinary Least Squared technique and also conducted the unit root and co-integration tests. The study showed that long run relationship exists among the variables. In addition, the core finding of this study showed that monetary policy rate, interest rate, and investment have insignificant positive effect on economic growth in Nigeria. Money supply however has significant positive effect on growth in Nigeria. Exchange rate has significant negative effect on GDP in Nigeria. Money supply and investment granger cause economic growth, while economic growth causes interest rate in Nigeria. On the overall, monetary policy explains $98 \%$ of the changes in economic growth in Nigeria. Thus, the study concluded that monetary policy can be effectively used to control Nigerian economy and thus a veritable tool for price stability and improve output.

The study Analysis of the Determinants of Dividend Payout of Consumer Goods Companies in Nigeria examines determinants of dividend payout of consumer goods companies listed on the Nigerian Stock Exchange. The Nigerian Stock Exchange has 28 listed consumer goods companies. Purposive sampling technique was used and a sample of nine consumer goods companies, for a duration of ten years, from 2006 to 2015, was selected. Secondary data was collected from the audited financial statements of the selected companies' websites. Dividend payout ratio was the dependent variable while independent variables were market value, profitability, financial leverage, firm size and previous year dividend payout. Descriptive statistics and multiple regressions were used. Results showed that firm market value has significant positive effect on dividend payout; firm profitability has positive, but insignificant effect on dividend payout; firm 18 


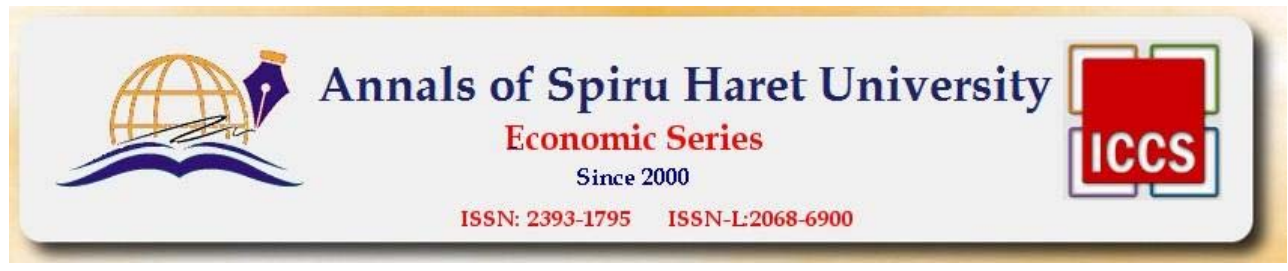

Issue 1/2018

leverage has negative and insignificant effect on dividend payout; firm size has negative and insignificant effect on dividend payout; and previous year's dividend has significant positive effect on dividend payout. The study thus concluded that market value and previous year's dividend are the major determinants of dividend payout in consumer goods sector in Nigeria.

In their paper called General Considerations on the Impact of Property on the Economic and Social Status of People, the authors are talking about property which is indissolubly linked to people's lives, forming part of it, being a permanent problem and occupying a particularly important place in economic, social, political and philosophical science.

Through the structure outlined in this short study, we are also trying to analyze the impact of ownership on people's economic and social status, relative to the concept of property and economic freedom.

Therefore, the impact of property as a multiple social relationship on the social status of people is relevant, namely the link between property and economic freedom, property and social justice, property and equality/inequality in society.

The subject of the article Self-Government Employee in the Polish Defence System on the Example of Mazowieckie Province, written by Jakub Adamkiewicz, is about the organization of local government authorities in the implementation of tasks related to security and defence. Attention is focused on issues of employment and organization of work. The tackled issues relate to adequacy of the knowledge and experience of employees to the extent of their professional duties, adapting the number of employees to the scope of tasks and public opinion on the activities of security offices. The article is based on the results of the qualitative and quantitative studies carried out within the framework of the project "Local selfgovernment in Polish non-military defence system" conducted by the Department of Security and Defence Systems of the Faculty of Logistics in Military, University of Technology, during 2015-2016, in Mazowieckie Province.

The study of prof. Haradhan Kumar Mohajan aims to investigate the food production and poverty reduction in Bangladesh in brief. Although the country faces various problems for the economic progress since its independent in 1971, in the last forty-eight years the increase of food production and poverty reduction in the country became remarkably. Bangladesh is a densely populated developing country in the southern Asia. The Government of Bangladesh is trying efficiently to reduce poverty of the country. In Bangladesh, about $20 \%$ of the populations still live below the poverty line, heavily undernourished, with inadequate access to safe and nutritious food for a healthy life. The data of the study were collected through the secondary 


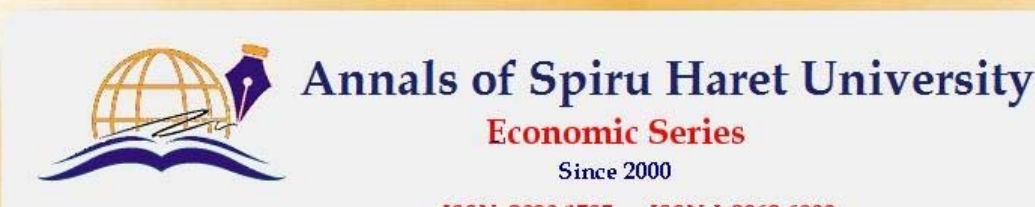

ISSN: 2393-1795 ISSN-L:2068-6900

\section{Issue 1/2018}

sources of the country. In Bangladesh, from 2000 to 2005, income poverty reduced from $48.9 \%$ to $40.0 \%$, from 2010 to 2016 it was reduced from $31.50 \%$ to $20 \%$, and in 2018 it is expected to decrease by $16 \%$. An attempt has been made here to show the ways to increase more the food production and poverty reduction of the country.

In her study entitled Study Regarding the Legal or Judicial Rehabilitation of Persons Engaged in Economic Activities, professor Amelia Diaconescu is talking about the consequences derived from any sentence pronounced for a crime committed by a major person pertain to the constitutional law, administrative law, civil law, family law, labour law or commercial law and consist in legal effects of criminal or extra-criminal nature, perpetual or long term ones which result from the fact of the criminal conviction itself and they place the convict in a disadvantageous situation.

Having a legal tool character by which the legal consequences resulting from a conviction cease or, in a larger sense, a legal tool character by which the exconvicts are legally reintegrated in the society, its effects consist in the same.

In her study called Future Modern Retail Solutions and Shopper Experience, professor Viorica Jelev is talking about artificial intelligence and automation that will radically change the world. She says that if we want society to benefit from these changes, we need to properly prepare ourselves through an education tailored to new times. Until the last century, it was the manufacturing industry that created jobs. But today, as a result of the existence of artificial intelligence, robots, the manufacturing industry is no longer the main driver of job creation, but the service industry.

As competition grows, brand manager imagination needs to work, and sales growth solutions need to focus on customer focus attention. It is a difficult task if all brands offer discounts in their shops from the malls and the differentiation notice is brought to the attention of specialists who offer solutions for any kind of fun for customers. The article aims to present the evolution of world trade in recent years and the various ways of diversion invented by retailers to keep customers in store chains a longer time in order to buy more.

The conclusion of this article will focus on the idea of future trade based on modern technology inside stores, which will lead to profound changes in customer buying behaviour.

Bogdan SOFRONOV, in his paper entitled The Impact of the Online Environment on Tourism, is talking about the online tourism that is part of the ecommerce and unites some of the fastest growing technologies, such as communications and information technology, the hospitality industry, and strategic management / marketing / planning. 


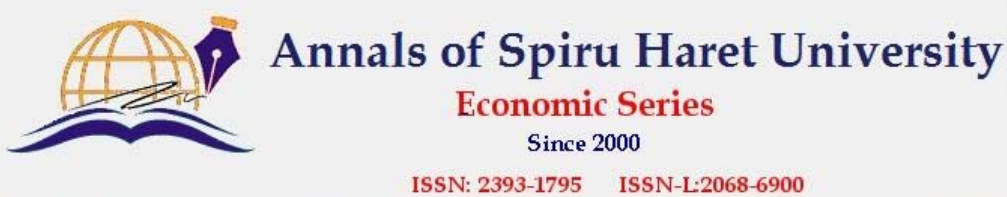

Online tourism activities involve tour operators, travel agencies and other entities with tourism-related interests in the virtual space through a dedicated portal. The phenomenon itself has implications for the tourist services consumer.

The Internet has revolutionized the travel industry both as a source of information and as a sales channel. Online marketing, photographs, and consumer reviews are bringing destinations and attractions to the screens of potential travellers around the world. The ease with which a customer can review and compare travel options opens up new markets for both large and small businesses and the ability to confirm prices and purchase services online benefits travellers and businesses alike.

As we have seen, all the articles are interesting and deserve to be appropriated by those who are interested in understanding the specific issues of the economy.

If you liked our articles, please visit our website. If you want to write an article in our journal, we are waiting for you to expose your ideas in new studies published by us.

Finally, hoping that you found interesting the Issue 1/2018, I strongly invite you to address your comments and suggestions at ashues@spiruharet.ro and, of course, to submit your own paper via the online submission system.

Research is the breath of the future. Let's shape the world together!

Associate Professor Elena GURGU, Ph.D.

Deputy Chief Editor 

ACADEMIA PAPERS 
